\title{
THE EFFECT OF TRANSFORMATIONAL LEADERSHIP AND HUMAN RESOURCE DEVELOPMENT ON JOB SATISFACTION AND ITS IMPACT ON JOB ENGAGEMENT
}

\author{
Pardede Muhammad Fajar Rahman Parulian*, Syah Tantri Yanuar Rahmat \\ Department of Management, Faculty of Economics and Business, Esa Unggul University, \\ Indonesia \\ *E-mail: fajarrahman790@gmail.com \\ ORCID: 0000-0001-9415-9888
}

\begin{abstract}
This study aims to determine and analyze the effect of transformational leadership and human resource development on job satisfaction and its impact on job engagement. It used a quantitative approach. Sampling was conducted by using non-probability sampling with saturation sampling technique. Thus, the total sample size was 176 samples. Data analysis in this study was carried out using structural equation modeling (SEM) analysis using the Lisrel 7.8 statistical program. The results of the study found that transformational leadership and human resource development had a positive and significant effect on job satisfaction. Moreover, transformational leadership, HR development and job satisfaction have a positive and significant effect on job engagement. This research has a contribution to PT. Wijaya Karya (Persero) Tbk (WIKA). In this case, company leaders need to be able to listen to various difficulties and complaints of employees regarding work. Therefore, it is important for superiors/company leaders and subordinates to work together to solve employee problems so that employee performance is maintained and company productivity increases. In addition, the company is also advised to carry out training activities and formal education.
\end{abstract}

\section{KEY WORDS}

Transformational leadership, human resources, job satisfaction, job engagement.

Job engagement displays deep and positive emotions to connect employees with work. Engagement requires leaders to support employees in solving problems and motivate them to be more committed (Mansor et al. 2017). In this case, leaders need to practice two-way communication in order to get the expected work results. Lai et al., (2020), Milhem et al. (2019), Arokiasamy \& Tat (2020), and Hawkes et al. (2017) found that transformational leadership has a significant effect on work communication of employee. Arokiasamy \& Tat (2020) tested four leadership behaviors including intellectual stimulation, idealized influence, inspirational motivation, and individualized considerations which found out that transformational leadership and job engagement are directly acceptable. This indicates that employees who have transformational managers tend to be energetic, dedicated and absorbed in work. A study on the effect of transformational leadership was also carried out by Gözükara \& Şimşek (2015) which concluded that full job independence affects the relationship between transformational leadership and job engagement.

Human Resource (HR) development can also be a factor in the emergence of a sense of job engagement between employees and the company since employees feel cared for and expect development in their careers. HR development by the company in the end will also affect level of satisfaction of employees with the tasks assigned by the company. Satisfaction can lead to a higher desire to remain engaged with the company. Yassin (2018) discovered that there is a significant effect of resource management practices on employee job engagement in the company.

Furthermore, focus of previous research by Lai et al. (2020) examined the effect of transformational leadership on job engagement. Besides, Milhem et al. (2019) studied the effect of transformational leadership on job engagement. Arokiasamy \& Tat (2020) examined the effect of transformational leadership on job engagement and workplace spirituality, while 
Hawkes et al. (2017) looked at the effect of transformational leadership and work resources on job engagement.

However, some of the current research (for instance, Lai et al. (2020), Arokiasamy \& Tat (2020). Hawkes et al. (2017) have not tested the effect of transformational leadership and HR development on job satisfaction as well as its impact on job engagement. Thus, this study adds job engagement variable as the impact of the effect of transformational leadership and HR development on employees' job satisfaction. The level of satisfaction becomes one of the motivators for a person or individual to feel the support from the company where they work Garg et al. (2018). Employees with a high level of satisfaction have a higher level of engagement than employees who do not feel satisfied with their work. Garg et al. (2018) affirmed that in today's dynamic environment, organizations face difficulties in retaining talented employees. More in-depth evaluation is needed to understand whether it is intrinsic or extrinsic job satisfaction that increases job engagement. Thus, the existence of job satisfaction can be a driving force for employee job engagement. Meanwhile, employee satisfaction is influenced by various factors such as the existing leadership style in the organization and the presence of organizational support in the form of human or employee development. Employee development is a factor that determines his satisfaction towards the company Jehanzeb \& Mohanty (2018). Importantly, Chandrasekara (2019) found that transformational leadership style has a positive relationship with employees' job satisfaction.

This study aims to examine and analyze the effect of transformational leadership and human resource development on job satisfaction and its impact on work participation.

\section{METHODS OF RESEARCH}

This study uses a quantitative approach to examine the relationship between four variables: transformational leadership, human resource development, job engagement, and job satisfaction as intervening variable. According to Bass \& Avolio (2004), there are four indicators to measure transformational leadership: 1) idealized influence, 2) inspirational motivation, 3) intellectual stimulation, and 4) individualized consideration.

Moreover, Noe (2017) claimed that indicators used to measure HR development include: 1) formal education, 2) appraisal, 3) work experience, and 4) interpersonal relationship. Additionally, job engagement variable according to Schaufeli et al. (2002) and Bakker (2010) is measured by the following indicators: 1) vigor, 2) dedication, and 3) absorption. Job satisfaction variable can be measured using the following indicators Spector (1985): 1) satisfaction with pay, 2) promotional opportunities, 3) fringe benefit, 3) contingent rewards, 4) supervision, 5) co-workers, 6) nature of work itself, 7) communication, and 8) work conditions. The conceptual framework in this study is described as follows:

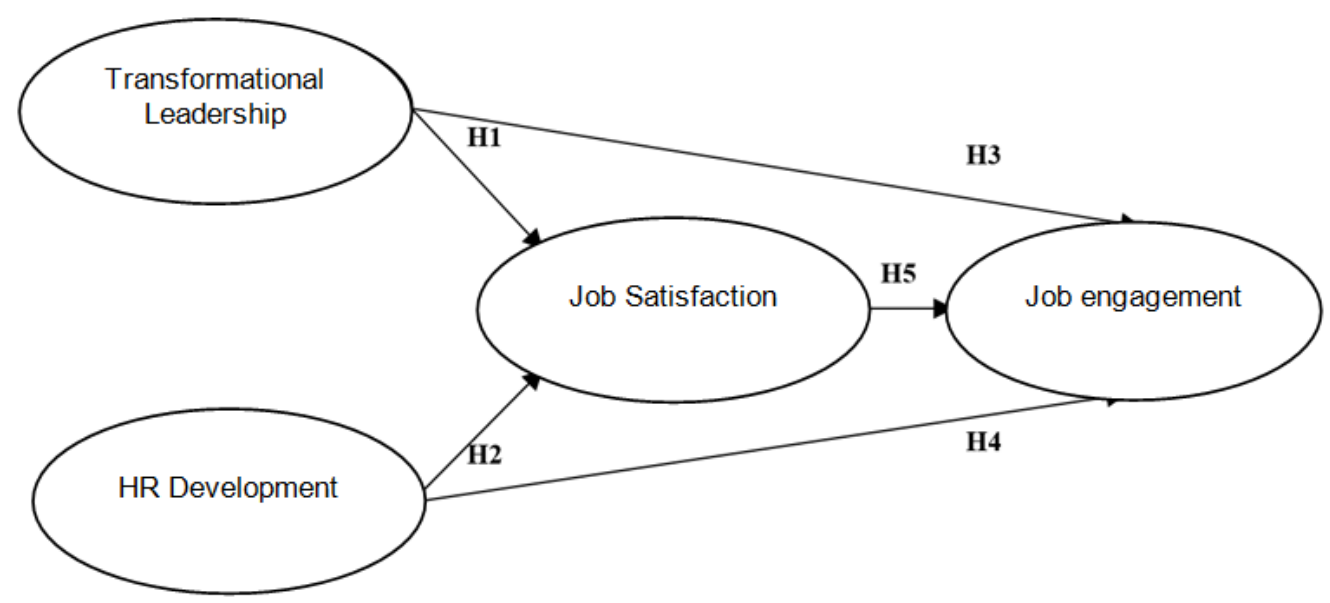

Figure 1 - Conceptual Framework* 
*Note:

- $\mathrm{H}:$ Hypothesis;

- H1: Transformational leadership will increase job satisfaction;

- H2: Human resource development will increase job satisfaction;

- H3: Transformational leadership will increase job engagement;

- H4: HR development will increase job engagement;

- H5: Job satisfaction will increase job engagement.

This research was conducted in April 2020 at the head office of PT. Wijaya Karya (Persero) Tbk (WIKA). WIKA is one of the largest State-Owned Enterprises (BUMN) engaged in the construction service sector in Indonesia. Sampling was carried out by nonprobability sampling method, which was conducted by means of sampling measurement or, in other words, saturation sampling. Saturation sampling is a sampling method in which all members of the population are used as samples (Sugiyono, 2016). Thus, since the total population in the study was 176 people, the sample was 176 samples. The survey was conducted by distributing online questionnaires to employees who work at the company at the staff position level.

In this questionnaire, a Likert scale is used as a form of level of importance (Sekaran \& Bougie, 2017). Likert scale contains a set of statements offered about the actual situation or case being studied. Respondents were asked to state the level of agreement (from strongly disagree to strongly agree) with statements made (data) on a scale of 1 to 5 . In order to obtain good research results, the data collection tool used, a questionnaire, was first tested for its validity and reliability to draw correct conclusions. Reliability is a test to measure the consistency of the instrument, while validity is a test that shows the correct condition (whether it is valid) of the instrument developed in measuring a particular concept of a study (Hair et al. 2014). Validity and reliability testing were carried out using Lisrel 7.8 software with the Confirmatory Factor Analysis (CFA) test. SEM analysis was performed using Lisrel 7.8 statistical program. In this study, transformational leadership style and HR development are exogenous variables, while job engagement and job satisfaction are endogenous variables. Hypothesis testing was done by looking at the results of the t-value with the provision of 1.96 (Hair et al. 2014). If the t-value is greater than 1.96, Ho is rejected and $\mathrm{Ha}$ is accepted. Conversely, if the t-value is less than 1.96 , Ho is accepted and $\mathrm{Ha}$ is rejected.

All indicators of human resource development and job satisfaction variables are declared valid. Additionally, 9 of 11 questions on transformational leadership variable were declared valid. In addition, 15 of 17 questions from job engagement variable were declared valid. Therefore, after conducting a pre-test analysis, 66 of 71 questions were declared valid to be used as a questionnaire.

\section{RESULTS OF STUDY}

This study utilized Lisrel (Linear Structural Relationship) 7.8 software to investigate the relationship of four variables including transformational leadership style, human resource development, job engagement, and job satisfaction. Research respondents were the entire population of 176 people. Characteristics of respondents in this study include sex, age, last education, and length of service. The majority of employees of PT. Wijaya Karya (Persero) Tbk with staff level positions were males (137 employees/77.8\%) and the rest were females (39 employees/22.2\%). Moreover, the majority of employees with staff level positions were between 25 - 35 years old (126 employees/71.6\%) Based on the level of education, the majority of employees of PT. Wijaya Karya (Persero) Tbk with staff level positions had earned bachelor's degree (110 employees/62.5\%). In terms of length of service, the majority of employees had worked for $>5$ years ( 80 employees $/ 45.5 \%$ ).

Construct validity and reliability were tested based on the recommendation from Hair et al. (2014); The observed variable, if it is feasible to be used as operational to the construct or its latent variable, must have a loading factor greater than 0.5 and a t-value greater than 1.96 so that the validity of the factor can be considered valid. Since the factor loading values were 
all suitable and good (>0.50) and the t-value was greater than the t-table (1.96) at the $5 \%$ significance level, all indicators on each variable of transformational leadership, human resource development, work satisfaction, and job engagement could be said to be valid. Based on the opinion of Hair et al. (2014), good reliability has construct reliability $>0.60$ and variance extracted $>0.50$. In this study, all variables met these requirements. Results of the calculation of all variables showed CR values above 0.60 and VE values above 0.50 with the following details: transformational leadership ( $C R=0.91 ; \quad V E=0.54)$, HR development $(\mathrm{CR}=0.93$; $\mathrm{VE}=0.62)$, job satisfaction $(\mathrm{CR}=0.98$; $\mathrm{VE}=0.87)$, job engagement $(\mathrm{CR}=0.93$; $\mathrm{VE}=0.81$ ). Further information on construct validity and reliability can be seen in Appendix 5.B.

Structural test analysis was conducted to determine the value of $R^{2}$ in each equation. The value of $R^{2}$ shows the extent to which the independent variable can explain the dependent variable. Based on the results of SEM analysis, several analysis results were obtained. The first one was that the job satisfaction variable was jointly influenced by the transformational leadership and HR development variables with an $\mathrm{R}^{2}$ value of 0.89 . It means that $89 \%$ of the variance of job satisfaction variable can be explained by transformational leadership and HR development variables, while the remaining $11 \%$ can be explained by other variables not included in this study.

The second analysis was that job engagement variable was jointly influenced by transformational leadership, human resource development, and job satisfaction variables with an $R^{2}$ value of 1.00 . It indicates that $100 \%$ of the job engagement variable can be determined by transformational leadership, human resource development, and job satisfaction variables.

Based on the suitability test analysis, most of the tests showed a good suitability including Chi Square, ECVI, AIC, CAIC, Fit Index, Critical N and Goodness of Fit. Based on the analysis results, it can be seen that there was a fit of all models (goodness of fit) even though some were still at the level of marginal fit. The complete data can be seen in appendix 5D.

Results of the research are demonstrated in the T-value diagram as follows:

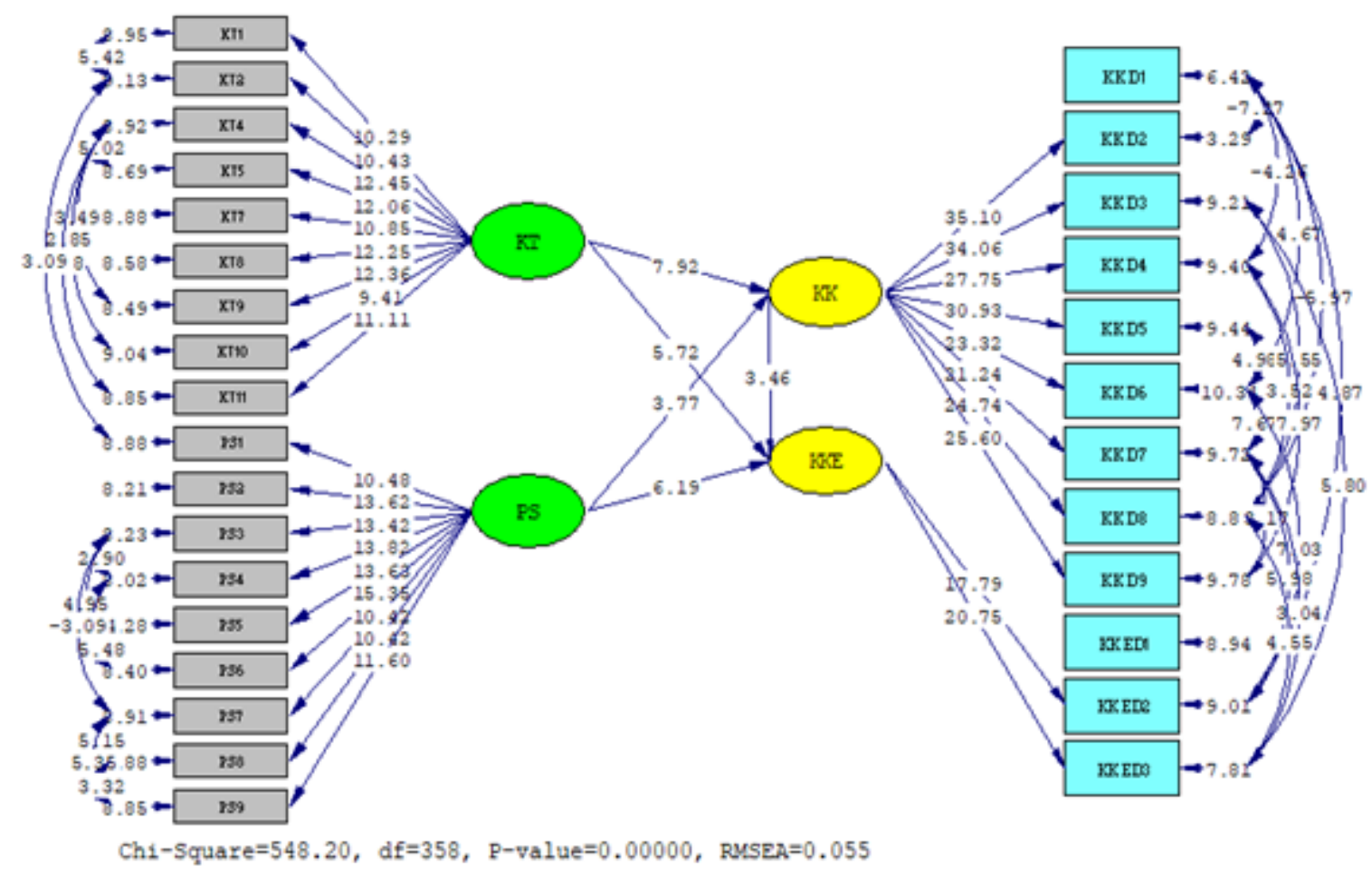

Figure 2 - T-Value Path Diagram 
Based on the t-value path diagram shown in Figure 2, the hypothesis testing model can be presented as follows:

Table 1 - Hypothesis Testing Model

\begin{tabular}{|c|c|c|c|}
\hline Hypothesis & Hypothesis Statement & T-Value & Explanation \\
\hline H1 & Transformational Leadership increases Job Satisfaction. & 7.92 & Data support the hypothesis. \\
\hline H2 & HR development increases Job Satisfaction. & 3.77 & Data support the hypothesis. \\
\hline H3 & Transformational Leadership increases Job engagement. & 5.72 & Data support the hypothesis. \\
\hline H4 & HR Development increases Job engagement. & 6.19 & Data support the hypothesis. \\
\hline H5 & Job Satisfaction increases Job engagement. & 3.46 & Data support the hypothesis. \\
\hline
\end{tabular}

Source: Lisrel Data Processing Results (2020).

Based on the hypothesis test table above, it is known that all variables have a T-Value above 1.96. Thus, data in this study support all the research hypotheses purposed. Complete information about the SEM analysis of this study can be seen in Appendix 5.

\section{DISCUSSION OF RESULTS}

Transformational Leadership Increases Job Satisfaction. Results of the hypothesis testing claimed that transformational leadership has a positive and significant effect on job satisfaction. It indicates that better implementation of transformational leadership in organizations will foster a collaborative approach, in which leaders and employees work together on a shared vision of the present and the future. In this case, employees' job satisfaction in the organization will get better. Transformational leadership encourages employees to go beyond self-interest and realization. This type of leader increases the sensitivity of subordinates about problems, consequences, growth, self-actualization, and dreams (Mansor et al. 2017). In transformational leadership, organizations are considered more effective in managing their members because they are more creative and able to inspire employees to be able to work outside their individual interests to achieve organizational benefits.

Khan et al. (2018) affirmed that transformational leadership is an effort to expand and improve employee benefits, increase the knowledge and promise of individuals in the organization to the objects and tasks of the organization as a mission, and allow employees to go beyond their own benefits for organizational excellence. Transformational leaders provide personal attention, encourage individualized consideration, introduce new ways of working in teammates, encourage their members to provide innovative solutions to solve problems, and provide training and enhance intellectual simulation of team members' behavior.

Leaders who are expected by company employees are leaders who can bring job satisfaction to their employees. It was mentioned by Jehanzeb \& Mohanty (2018) that job satisfaction is an important factor that can affect employees' life satisfaction because they spend most of their time working. Job satisfaction is a complex feature since it is influenced by a number of factors, one of which is leadership style.

Results of this study are supported by research conducted by Chandrasekara (2019) and Rahmawati \& Tobing (2019) which found that transformational leadership style has a positive relationship with employees' job satisfaction.

HR Development Increases Job Satisfaction. The second hypothesis is accepted because human resource development has a positive and significant effect on job satisfaction. It indicates that the more human resource development a company provides to its employees, the higher the level of job satisfaction that employees feel. Developing employee skills and abilities provides psychological and emotional bonding over employees, thereby encouraging employees to reciprocate through greater engagement at work and efficient execution of assigned work within the organization while making them more valuable in the external world of work (Jehanzeb \& Mohanty, 2018). 
Employee development, according to Noe (2017), includes training, formal education, work experience, interpersonal relationships, assessments, skills and competencies that help employees prepare for future jobs and careers such as individual personal and professional growth from a long-term personal perspective. Employee development is a factor that determines employee satisfaction with his company (Jehanzeb \& Mohanty, 2018). It can provide more satisfaction to employees so that there is a higher sense of belonging to the company

Al-Mehrzi \& Singh (2016) believed that job engagement is an important element in determining organizational success. Therefore, it must be supported by actions that can give each employee a sense of belonging, one of which is by human resource development. Results of this study also support a study conducted by Yassin (2018) which found that human resource practices have an effect on employee job engagement in the company.

Transformational Leadership Increases Job Engagement. The results of the third hypothesis show that transformational leadership has a positive and significant effect on communication. In teamwork, transformational leaders provide holistic and challenging but attainable goals, and encourage followers to look beyond their personal interests to achieve collective goals. Transformational leaders encourage members to effectively use intelligence or experience, view problems from multiple angles, master the problem-solving process, and determine the best solutions to increase efficiency. The results of this study support the previous findings such as Arokiasamy \& Tat (2020) and Hawkes et al. (2017) which found that transformational leadership affects job engagement. This implies that the leader can offer sufficient resources (e.g. physical, emotional, or psychological) to members to try new solutions to task-related problems. It probably produces psychological availability and increases members' job engagement (Lai et al., 2020).

HR Development Increases Job Engagement. Human resource development has a positive and significant effect on job engagement. This indicates that the fourth hypothesis is accepted. Engaged workers have an energetic and effective drive to complete the task at hand. Employees act with confidence and see themselves competently handling the challenges that arise from the work being performed. Jehanzeb \& Mohanty (2018) claimed that employee development provides increased positive results that are expected to continue to increase by involving in job training, reducing employee turnover and absences, better employee commitment, establishing an internal structure, developing a solid career, increasing teamwork, and exchanging relationships. Career development has an important advantage in organizations, which is the improvement of employee skills through high quality training in the career development process so that it can be adjusted to the needs of the company.

It is in line with results of study conducted by Yassin (2018) which concluded that resource management practices have an influence on employee job engagement. It demonstrates that employers need to develop appropriate and well-structured HR policies to achieve a high level of job engagement among employees.

Job Satisfaction Increases Job Engagement. The results in this study indicate a positive and significant effect between job satisfaction and job engagement. It means that job satisfaction is an individual's view of his job. Someone who is positive about their job has a high level of job satisfaction. More importantly, job satisfaction can be defined by comparing employees' expectations of their work and work results. This is related to the optimistic mindset of employees towards work and has been evaluated based on their point of view. It is basically a simple principle believing that employees who are satisfied with their jobs tend to be connected to the organization. In other words, they automatically work with a higher commitment, resulting in organizational success (Mazeed et al., 2019).

In fact, people who have low job satisfaction have an unhappy attitude about their work. Job-related emotions include factors such as salary received, career development opportunities, relationships with other employees, job assignments, the organizational structure of the company's work, and quality of management. At the same time, feelings about it include age, health, abilities and education. 
Additionally, job engagement is a state of positive, satisfying, and affective motivation from work-related well-being which can be seen from work fatigue. Employees have high energy levels and are willing to participate in their work ((Arokiasamy \& Tat, 2020). It is in line with Garg et al. (2018) who asserted that there is a positive relationship between job satisfaction and job engagement. Previous research that is consistent with these findings was conducted by Hasibuan (2019) and Alzyoud (2018), finding that employee satisfaction has a positive and significant impact on job engagement.

\section{CONCLUSION}

The first research result is that transformational leadership has a positive and significant effect on job satisfaction. This means that the implementation of better transformational leadership in organizations will encourage a collaborative approach in which leaders and followers or members work together in a common vision of the present and the future. The second result shows that human resource development has a positive impact on job satisfaction. This means that the more human resource development that the company provides to its employees, the higher the level of employee job satisfaction. The third test result states that transformational leadership has a positive effect on work participation. Transformational leaders set challenging but achievable goals, and encourage members to look beyond their personal interests to achieve group goals. Moreover, the fourth research finding shows that human resource development has a positive and significant effect on work participation. This demonstrates the need for employers to develop appropriate and wellorganized human resource policies to achieve high levels of employee engagement.

There are still some limitations that need to be improved in the future. Firstly, this research is limited to one organization at the staff position level at PT. Wijaya Karya (Persero) Tbk so that it is not necessarily able to describe the conditions or represent other level organization positions. In the future, the same research can be carried out by involving not only one level of position or organization. Secondly, the learning and innovation process in organizations is not an instant process and takes time before changes occur. Thus, cross sectional research can be less precise, while longitudinal research is recommended. Thirdly, besides transformational leadership and human resource development, there are other factors that can influence job satisfaction and job engagement, such as training, organizational culture, and motivation.

Researchers only analyze the effect of transformational leadership and human resource development on job satisfaction and its impact on work participation. Further research is expected to carry out other research by including other variables that can affect job satisfaction and job engagement such as work environment, workload, and organizational culture. Last but not least, research variables can be added with other variables that can also determine job satisfaction and job engagement to the company such as work environment, compensation, and organizational culture. Therefore, it will be possible to know the dominant factors that influence the formation of employee satisfaction and job engagement.

\section{MANAGERIAL IMPLICATIONS}

Based on the results of tests that have been carried out through statistical calculations, the managerial implications in this study are: in transformational leadership variable, company leaders are advised to be able to treat each subordinate as an individual and accompany, monitor and foster opportunities according to the needs and abilities of employees so that each employee can increase creativity and innovation. Furthermore, in the HR development variable, the company is advised to provide training and employee development programs in the form of providing internal training or sending employees to attend training outside the company or providing scholarship opportunities to take further formal education. This will help employees build the basic knowledge they should have at a certain level or position. Meanwhile, on the job satisfaction variable, the company is advised to create a good relationship between employees or co-workers. Good relationships among 
colleagues can provide comfort at work. In the job engagement variable, company leaders are advised to provide motivation to employees so that employees feel valued, respected and enthusiastic to achieve company goals, which in the end they will have a sense of engagement to the company.

\section{REFERENCES}

1. Al-Mehrzi, N., \& Singh, S. K. (2016). Competing Through Employee Engagement: A Proposed Framework. International Journal of Productivity and Performance Management, 65(6), 831-843. https://doi.org/10.1108/IJPPM-02-2016-0037.

2. Alzyoud, A. A. Y. (2018). Job Satisfaction and Work Engagement Moderated By Trust. International Journal of Economics, Commerce and Management, 6(11), 125-139. https://doi.org/10.2466/pr0.1991.69.3f.1116.

3. Arokiasamy, A. R. A., \& Tat, H. H. (2020). Exploring the influence of transformational leadership on work engagement and workplace spirituality of academic employees in the private higher education institutions in Malaysia. Management Science Letters, 10(4), 855-864. https://doi.org/10.5267/j.msl.2019.10.011.

4. Bass, B. M., \& Avolio, B. J. (2004). Multifactor Leadership Questionnaire. Manual and Sampler Set (3rd ed.). Mindgarden.

5. Chandrasekara, W. S. (2019). The Effect of Transformational Leadership Style on Employees Job Satisfaction and Job Performance: A Case of Apparel Manufacturing Industry in Sri Lanka. International Journal of Economics, Commerce and Management, 7(7), 385-393. https://doi.org/10.17148/iarjset.2019.6802.

6. Garg, K., Dar, I. A., \& Mishra, M. (2018). Job Satisfaction and Work Engagement: A Study Using Private Sector Bank Managers. Advances in Developing Human Resources, 20(1), 58-71. https://doi.org/10.1177/1523422317742987.

7. Gözükara, İ., \& Şimşek, O. F. (2015). Linking Transformational Leadership to Work Engagement and the Mediator Effect of Job Autonomy: A Study in a Turkish Private NonProfit University. Procedia - Social and Behavioral Sciences, 195, 963-971. https://doi.org/10.1016/j.sbspro.2015.06.274.

8. Hair, J. F., Black, C. W., Babin, J. B., \& Anderson, E. R. (2014). Multivariate Data Analysis (7th editio). Pearson Prentice Hall.

9. Hasibuan, H. A. (2019). Domination of Job Satisfaction in Moderate Influence Transformational Leadership Towards Employee Engagement ASN Employees. IOSR Journal of Business and Management, 21(9), 1-6. https://doi.org/10.9790/487X2109020106.

10. Hawkes, A. J., Biggs, A., \& Hegerty, E. (2017). Work Engagement: Investigating the Role of Transformational Leadership, Job Resources, and Recovery. Journal of Psychology: Interdisciplinary and Applied, 151(6), 509-531. https://doi.org/10.1080/00223980.2017.1372339.

11. Jehanzeb, K., \& Mohanty, J. (2018). Impact of Employee Development on Job Satisfaction and Organizational Commitment: Person-Organization Fit as Moderator. International Journal of Training and Development, 1-21. https://doi.org/10.1111/ijtd.12127.

12. Khan, I. U., Hasnain, S. A., Ullah, S., \& Khalid, A. (2018). Impact of Transformational Leadership on Employee's Job Satisfaction and Well-Being Through Team Efficacy in PMBMC. International Journal of Human Resource Studies, 8(1), 327-339. https://doi.org/10.5296/ijhrs.v8i1.12521.

13. Lai, F. Y., Tang, H. C., Lu, S. C., Lee, Y. C., \& Lin, C. C. (2020). Transformational Leadership and Job Performance: The Mediating Role of Work Engagement. SAGE Open, 10(1). https://doi.org/10.1177/2158244019899085.

14. Mansor, Z. D., Mun, C. . P., Farhana, B. S. N., \& Tarmizi, W. A. (2017). Influence of Transformation Leadership Style on Employee Engagement among Generation Y. International Scholarly and Scientific Research \& Innovation, 11(1), 161-165. 
15. Mazeed, S. A., Saritha, P., Begum, N., Illangi, C. B., \& Manjula, G. (2019). Job Satisfaction and Employee Engagement - Contemporary Tools to Eliminate Stress among Work Force in an Organization. International Journal of Innovative Technology and Exploring Engineering, 8(11), 1744-1746. https://doi.org/10.35940/ijitee.k1531.0981119.

16. Milhem, M., Muda, H., \& Ahmed, K. (2019). The Effect of Perceived Transformational Leadership Style on Employee Engagement: The Mediating Effect of Leader's Emotional Intelligence. Foundations of Management, 11(1), 33-42. https://doi.org/10.2478/fman2019-0003.

17. Noe, R. A. (2017). Employee Training and Development (Employee T). McGraw-Hill Education.

18. Rahmawati, R., \& Tobing, D. S. K. (2019). The Role Of Transformational Leadership On Organizational Commitment And Job Satisfaction Of Tax Office Officers (KPP) In Banjarmasin. International Journal of Scientific and Technology Research, 8(7), 11-17.

19. Schaufeli, W. B., Salanova, M., Roma, V. G., \& Bakker, A. B. (2002). The Measurement of Engagement and Burnout: A Two Sample Confirmatory Factor Analytic Approach. Journal OfHappiness Studies, 3, 71-92.

20. Sekaran, U., \& Bougie, R. (2017). Metode Penelitian untuk Bisnis: Pendekatan Pengembangan-Keahlian, Edisi 6, Buku 1, Cetakan Kedua. Salemba Empat.

21. Spector, P. E. (1985). Measurement of human service staff satisfaction: Development of the Job Satisfaction Survey. American Journal of Community Psychology, 13(6), 693713. https://doi.org/10.1007/BF00929796.

22. Sugiyono. (2016). Metode Penelitian Kuantitatif, Kualitatif dan R\&D. PT Alfabet.

23. Yassin, A. A. A. (2018). The Influence of Human Resource Management Practices on Employee Work Engagement. Foundations of Management, 10(1), 251-256. https://doi.org/10.2478/fman-2018-0019. 